\section{Challenges on Urban Socio-Spatial Cohesion. The Case of Social Housing Complexes in the Regional Administrative Area of Piraeus in Greece}

\section{Tousi Evgenia*}

University of West Attica, Department of Interior Architecture, Grece

*Corresponding author: etousi@uniwa.gr

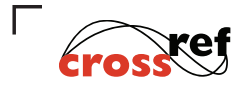

http://dx.doi.org/10.5755/j01.sace.29.2.29137
The regional administrative area of Piraeus has long been a suitable case study for analyzing the impact of social housing. The six municipalities that constitute this urban agglomeration have been strongly connected with the Asia Minor Catastrophe of 1922 and the consequent rehabilitation of the refugee population during the 30s. Moreover, after WWII, more social housing complexes had been constructed in the urban area around central Piraeus, representing different architectural types and principles. Today, they host various socio-economic population groups. Economic immigrants and households of elderly people are some of the vulnerable households that reside today in the social housing apartments. One major issue is the poor housing conditions and the low level of preservation associated with high rates of poverty and social exclusion. This paper attempts to depict the contemporary situation in the area by providing thematic cartography with the aim of indicating crucial enclaves in need of urban regeneration.

Keywords: social housing, socio-spatial inequalities, Greece, social exclusion.

The history of social housing dates back to the early $19^{\text {th }}$ century. It began as a voluntary, philanthropic activity and gradually transformed to a centralized public policy (Braga et.al., 2013). Being strongly associated with the living conditions of the working class in the industrial centers of the Global North, it was located in specific areas within the urban fabric. From this point of view, many cities around the world have been severely affected by the implementation of social housing programs that create urban enclaves with certain socio-economic attributes (Massey and Denton, 1993, Bratt, 19986).

The presence of social housing in different political systems is connected to a variety of social policies that aim to ameliorate social exclusion. In the capitalistic world, different approaches of social housing highlight discrete phases of the capitalistic system (Harloe,1995). The first industrial period is characterized by limited State intervention, while the years 1945-1960 describe the "golden era" of social housing. During this period, various programs were enacted with the view to offer affordable housing to a wide range of beneficiaries. However, the international economic crisis during the 70s put an end to this approach. Following the worldwide economic instability, the
JSACE 2/29

Challenges on Urban SocioSpatial Cohesion. The Case of Social Housing Complexes in the Regional Administrative Area of Piraeus in Greece

Received $2021 / 05 / 31$

Accepted after revision 2021/06/29

\section{Introduction}

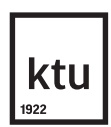

Journal of Sustainable Architecture and Civil Engineering Vol. 2 / No. 29 / 2021

pp. 21-32

DOI 10.5755/j01.sace.29.2.29137 
post-Fordist era was distinguished by globalization procedures that determined the physiognomy of social housing projects around the world. On the other hand, in the former USSR, housing policies were based on collectivization of land properties (Andrusz, 1984) offering a different perspective on the housing issue. The sense of community property led to different forms of residential patterns (Papadopoulou, 1995 and Stadelbauer,2006).

Following patterns of capitalistic socio-economic development with local specificities, Greece's social housing policies are strongly connected to the Asia Minor Catastrophe of 1922. Prior to this, no centralized polices are recorded, despite the need for social provision in the housing sector (Gizeli, 1989). The rehabilitation after the vast demographic flow of more than 1.500 .000 refugees, created socio-spatial patterns of exclusion after the establishment of the social housing enclaves outside the perimeter of the existing city (Leontidou, 2017). Most of the refugee settlements were located near industrial units 1 to $4 \mathrm{Km}$ far from the boundaries of the non-refugee urban areas (Sarigiannis, 2000). This rehabilitation policy, included a variety of strategies from distribution of plots to apartment construction. During this venture, many actors played a key-role as the National Bank of Greece, The Fund for Refugee Rehabilitation, the Ministry of Social Welfare, the Committee for the Refugee Rehabilitation and other (Gizeli, 1989). In this urban context, the dichotomy of refugee and non-refugee areas prevailed until the 1950s.

After the Second World War, the establishment of the Worker's Housing Organization inaugurated a new era in the social housing sector. This is considered to be the only Organization that played a meaningful role in providing affordable housing, including apart from the refugee's some other population groups, mostly segments of the working class and lower middle-class strata (Tousi, 2019). At this point it is important to mention, that Greek social housing does not include rental housing units, apart from a Worker's Housing Organization Program that subsidized the beneficiaries so as to rent apartments from private owners. The geography of the Worker's Housing Organization building complexes, goes beyond the dichotomy of refugee and non-refugee urban areas, following different principles. Nonetheless, these social housing complexes are mostly located in working class residential areas. The Memorandum of 2012, as a consequence of the economic crisis of 2008, ordered the closure of the Worker's Housing organization, leaving a large number of households without public support. As stated in a European Report of 2012 (CECODHAS, 2012), the phenomenon of "hidden homelessness" is a major issue in Greece, since many population groups are not able to cover the expenses of a rental housing unit. In addition, these population groups do not have the funds for purchasing a single-family house or an apartment. Thus, they are depended on their ancestors so as to cover their basic housing needs. This interrelation has significant social ramifications, affecting mostly young people that are unable to run an independent living. These problems are observed in many urban and rural areas of the country.

In Piraeus, the development of social provision in the housing sector is connected to the refugee population of 1922. During the 30s, the refugees doubled the population of the city. They were initially hosted in the Municipal Theater of the city and in open public spaces while the State inaugurated the transformation of private and public land into refugee settlements (Koutelakis, 1991). Today, the regional administrative area of Piraeus includes six municipalities (Nikea-Rentis, Keratsini-Drapetsona, Korydallos, Perama and Piraeus). These municipalities were developed during the refugee rehabilitation. Thus, we observe numerous social housing complexes that host today vulnerable households, mostly elderly people and economic immigrants. This administrative area includes a variety of architectural types as far as social housing is concerned. Moreover, these buildings have been constructed during different chronological periods by different organizations. In particular, the municipalities Nikea-Rentis, Keratsini-Drapetsona and Perama preserve enclaves with refugee houses while in Piraeus and Korydallos the State offered plots to the refugee population. Additionaly, Worker's Housing Organization Housing Complexes can be found in scat- 
tered enclaves of the Municipality of Rentis. Drapetsona has social housing complexes constructed by the Ministry of Welfare, of similar morphology to the Worker's Housing Organization buildings.

One crucial issue is the level of preservation of the social housing stock. As observed during field work, there are enclaves of social exclusion with poor housing facilities and households below the threshold of poverty. This crucial issue of socio-spatial exclusion as met in the contemporary urban fabric, is timely and needs addressing so as to outline the blighted urban areas. The aim of this paper is to offer important information about the contemporary condition of the social housing enclaves in the regional administrative area of Piraeus through original cartographic depiction. These research findings might function as a useful tool for further research or for constructing strategic planning for these areas so as to counterweight the negative effects of urban degradation.

The regional administrative area of Piraeus is used as a case study because of the variety of social housing enclaves that it hosts. The area of study presents almost all the types of social housing complexes as constructed in Greece since the 30s. This paper presents some of the findings of author's post-doctorate research, that took place form 2016 until 2019. The research is based on literature review and field work. Literature review has taken into account the international experience on the field as well as publications focusing on the case of Greece. Moreover, archival material has been studied from the Ministry of Welfare (old maps), the Worker's Housing Organization (drawings, maps, tables and publications) and census data from the Hellenic Statistical Authority. Apart from these, the Technical Departments of the Municipalities of the Regional Administrative area of Piraeus offered cartographic material and official aerial photographic depictions of the selected enclaves, in different chronological periods. Research has taken also into consideration the typology ETHOS, where various categories include potentially homeless people residing in unbearable living conditions (categories 8.2, 12 and 13.1). The main research question revolves around the detection and cartographic depiction of crucial enclaves within the borders of the Regional Administrative area of Piraeus, which is under major transformations because of the opening up of the local economy to foreign investors (Tousi and Serraos, 2020).

Field work took place from April 2018 to March 2019. It included direct observations, interviews and cartographic depiction. The researcher visited all the existing social housing enclaves of the Regional Administrative area of Piraeus and made direct observations. After collecting empirical findings for all these areas, the researcher selected three areas of focus that are representative of each social housing type. Thus, the selected neighborhood in Nikea hosts two-storey refugee blocks of flats, the enclave in Rentis a Worker's Housing Organization Complex and the neighborhood in Palaia Kokkinia a social housing enclave constructed by the Ministry of Social Welfare. These three enclaves are typical and characteristic for each type of social housing.

Field work comprised also qualitative research with 20 semi-structured interviews in each area of focus (one neighborhood in Nikea, one neighborhood in Rentis and one neighborhood in Palaia Kokkinia in Piraeus). Moreover, field work included interviews with three key-participants, former employees of the Workers' Housing Organization, so as to offer insights into the operation of the organization. The information collected from the interviews was analyzed and evaluated together with the findings of the direct observations. The participants in the interviews were selected randomly with the help of critical case sample. In this method subjects share a common experience. The critical factor for this research was at least one year sojourn in the area. The thematic units of the interviews include the socio-economic attributes of participants, their opinion about their apartments and their neighborhood and the opportunities for access to public services and resources, so as to address issues related to social exclusion.

Furthermore, data collected from direct observations and archival material were depicted in maps as organized into the three following categories; year of construction, organization of construction 
Theoretical Framework and level of preservation. These thematic maps could be used as a useful tool for implementing strategic planning in the area, since they highlight the existing crucial enclaves that suffer from dereliction. In addition, the material selected during the interviews was analyzed and incorporated into the rest of the findings so as to contribute to an overall socio-spatial assessment of the area of study. All the resources used during the research contributed to the adumbration of the physiognomy of the social housing enclaves in the Regional Administrative area of Piraeus, outlining the presence of crucial enclaves. The methodology implemented in this research has a pilot character and is eligible for application in other areas that share common socio-spatial attributes.

\section{The Connection Between Social Housing and Social Exclusion}

According to international literature, there is a strong connection between social housing and social exclusion. Limited social mobility is observed in people residing in social housing enclaves, expressing high risk of social exclusion. The criteria of evaluation are usually connected with the quality of housing facilities, the educational level, the access to public services and the employment opportunities (Jensen-Holt,2000). As mentioned in the chapter of Methodology, these parameters have been taken into consideration during field work. The interrelation between housing conditions and social exclusion is outlined through the United Nation's Human Development Index. On account of this index there are three critical parameters; life expectancy, knowledge and decent housing conditions (United Nations, 2006). Elements of these three dimensions compose the final indicator that reveals correlation among poverty, educational level and housing conditions (ibid). On account of all these, the assessment of the housing conditions is a basic criterion for pointing out the risk of social exclusion.

A brief overview of the international literature on the field, shows that the majority of definitions relate social housing tenants to social exclusion. A significant number of definitions, puts emphasis on the distinction between poverty and exclusion as found in the work of Fraser (2003) and Fleury (1998). Supporting Mazel's view, they claim that all forms of exclusion are not associated with poverty (Mazel,1996). Other definitions ascribe a nodal role to the prevailing notion of the society that blames the subjects of exclusion for their condition (Juliano,2001). There are also many definitions that focus on the spatial dimension of the phenomenon of social exclusion, describing neighborhoods and areas as deprived from public resources and services (Byrne,1999, Pierson, 2002 and Estivill, 2003). In total, most of the definitions highlight the restricted access and the disempowerment of people as unable to exercise their basic rights (Levitas et al., 2007 and Burchardt et al., 1999).

At this point it is important to mention that the introduction of the term dates back to the $60 \mathrm{~s}$. The term was found in the work of Pierre Masse, «Les dividendes du progres». During the same period, in 1965, the term was also used in the work of J. Klanfer, "L' exclusion social». However, social exclusion was strongly associated with the work of Rene Lenoir (1974), entitled "Les exclus, un Francais sur dix». The socio-economic context during that period described an era of prosperity, where effort was made to ameliorate the existing socio-economic discrepancies. The French tradition on the issue of exclusion has influenced pertinent policies of the European Union, leading to strategies against social exclusion (Spicker,1998). The Social Protocol as found in EU's official publications, in Maastricht's Convention, expresses the need to combat social exclusion as a necessary step for achieving social and spatial cohesion (Poggio, et.al, 2017). Relevant reference is being made in the Convention of Amsterdam. According to all these, social provision in the housing sector is an official target for all member states of the EU (Whitehead 2007 ka 2008).

However, skepticism on the effect of social exclusion policies is recorded by numerous scholars. According to Schnapper (2011) the problem is related to the nature and implementation of such a type of policy that stigmatizes the beneficiaries. Based on Paugam's view (1996), these policies 
reproduce the same model that generated exclusion. Thus, there is a binary social taxonomy of included and excluded. As Paugam claims, in modern societies, social policies are simultaneously unavoidable and inefficient (ibid). Recent literature on the issue, reveals another aspect of social exclusion, associated with geographical mobility. The phenomenon of "neighborhood effects" is delineated as a separate socio-economic phenomenon with certain spatial expressions. The geography of neighborhood effects, comprises degraded urban areas often hosting social housing complexes. Based on empirical findings, people residing in social housing enclaves present restricted social and geographical mobility, low educational level, high rates of unemployment and poor living conditions. Additionally, there is a trans-generational transfer of socio-economic attributes according to empirical findings. From this point of view, the "Moving to Opportunity Programm" (MTO) in the U.S.A., tried to look in depth the association between social housing and social mobility (Ludwig at.al, 2008). In parallel, strategies for mixed-income neighborhoods try to reduce the risk of exclusion when enacting an affordable housing area-based policy (Oberleke, 2000). Despite the efforts, the phenomenon of neighborhood effects is still active, trapping neighborhoods, households and individuals in the vicious cycle of degradation (Maarten van Ham et.al, 2012).

New challenges in the era of globalization order new research tools so as to ameliorate unbearable living conditions in the metropolitan areas of the Global North. Refugee and immigration demographic flows affect many metropolitan areas in Europe and especially in Greece, putting in the forefront, more intensely than ever, the issue of exclusion. To be more specific, according to research data (Tousi, 2014) immigrants are found in former social housing enclaves in Piraeus, because of the low rents. At this point it is important to clarify that there is a special regime on the social housing apartments in Greece that differentiates the implemented policy from the European equivalent. This special condition involves the ownership of the social housing apartment after the disbursement of the specified amount. This means that when the beneficiaries manage to amortize the mortgage, they end up owning the apartment. In this respect, many descendants of the initial beneficiaries have rented their apartment and moved to other residential areas. Thus, the former social housing complexes are not anymore under public consideration; the apartments belong to private owners after the payout. This situation concerns all the post-refugee settlements constructed during the rehabilitation project of the 30s, as well as the Worker's Housing Organization constructions.

It is also important to mention that the term "social exclusion" became popular in Greece during the 90s. Scientific dialogue on the issue has revealed numerous forms of exclusion associated not only with poverty but also with limited access to welfare services, as recorder by the National Center for Social Research. Today, according to Eurostat's statistics, the issue of exclusion is timelier than ever, affecting a significant number of households in Greece (Eurostat, 2019). Based on Eurostat's findings, $34,8 \%$ of the overall population in Greece is at risk of exclusion while the European medium is estimated around 22,4\%. Some other important findings (Eurostat,2017), reveal that there is no social provision for the housing sector in Greece, as only $0,2 \%$ of the overall amount is allocated to affordable housing programs. Since the economic crisis of 2008 , the situation has deteriorated rapidly, reducing the above-mentioned percentage to $0 \%$ in 2014 . This percentage is associated with the closure of the Worker's Housing Organization in 2012.

These findings highlight the necessity to address the issue of social housing in Greece, taking into account the existing social housing reserve and its potential for renovation, so as to cover citizen's contemporary needs. However, the urban blight met in the majority of the social housing enclaves outlines the challenges that public policy should handle so as to foster socio-spatial cohesion, avoiding severe segregation. The regional administrative area of Piraeus, is a suitable field for studying in depth all the aforementioned issues, focusing on the potentialities and challenges as met during field work. 


\section{Results and Discussion}

\section{Cartographic depiction of social housing enclaves in the Regional Administrative area of Piraeus}

According to field work, the area of study includes a variety of different social housing enclaves, constructed by different organizations. Apart from the central area of Piraeus (see map 1) all neighboring municipalities include enclaves related to the urban refugee rehabilitation after the Asia Minor Catastrophe in 1922. As depicted in Map 1, many spatial units around the central area of Piraeus were subject to compulsory purchase so as to facilitate the urban refugee rehabilitation. Dating back to 1924, the Fund for the Refugee Rehabilitation and the Committee for the Refugee Rehabilitation created urban refugee settlements around the central municipality of Piraeus. The largest such enclave that still preserves almost $40 \%$ of the old housing reserve, is the historical center of Nikea. Apart from the case of Nikea, the other compulsory exchanges of land had a fragmented character, because of a variety of reasons. One major factor was the topographic anaglyph; thus, in the cases of Keratsini and Amfiali, where significant inclination of land is observed, the refugee enclaves are scattered. Another factor is associated with the already existing land uses prior to the refugee inflow. As in the case of Drapetsona, the presence of manufacturing units as well as the neighboring worker's housing complexes, determined the location of the refugee enclaves.

\section{Map 1}

Compulsory purchase of land during the 1930s, representative examples, author's field work, study of archival material from the Ministry of Social Welfare and the Historical Archive of the Municipality of Piraeus

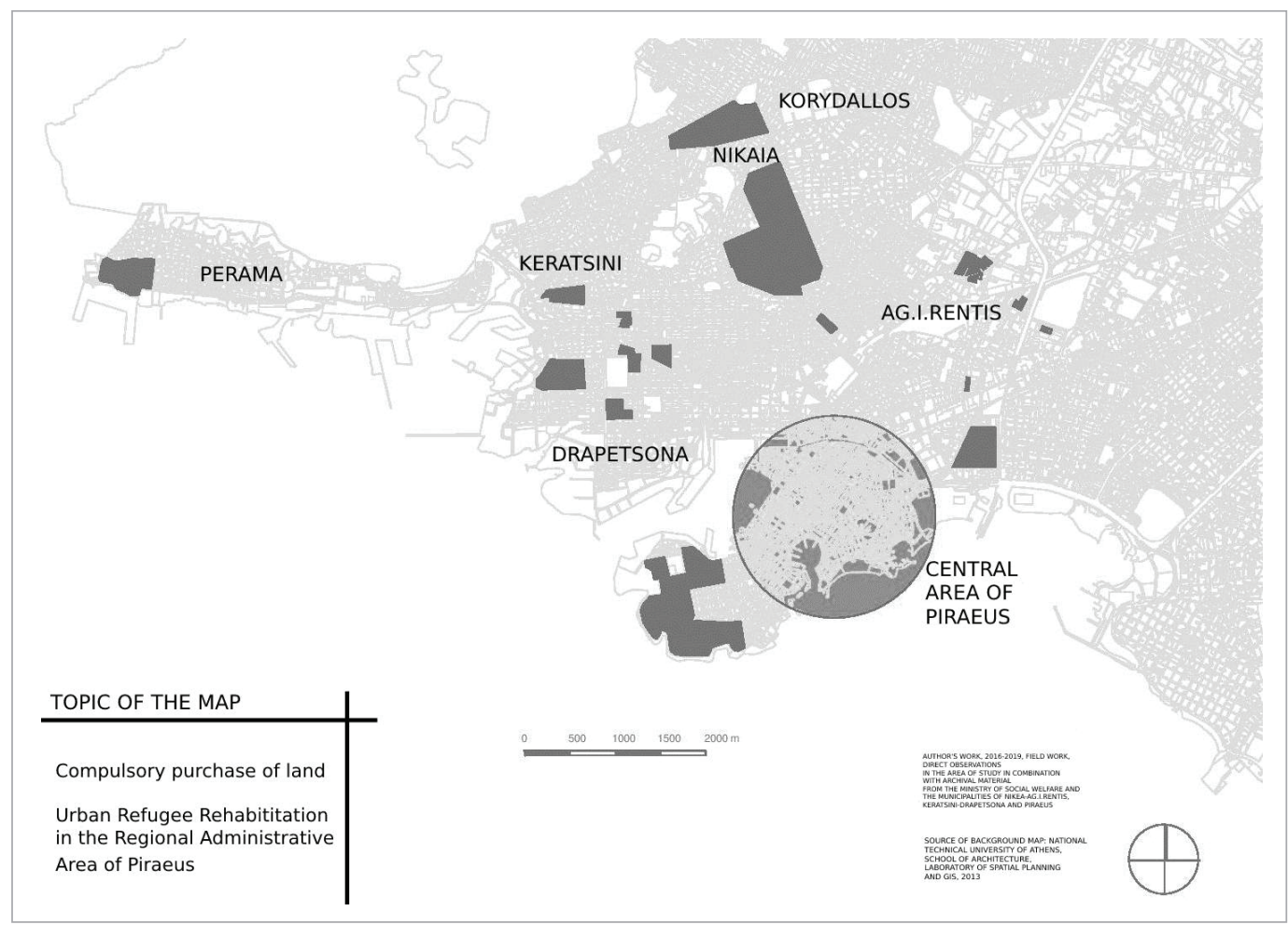

On the other hand, the area of Agios loannis Rentis, included mostly agricultural land and as a consequence the refugee enclaves were intercalary to the existing agricultural sites. After the $2^{\text {nd }}$ World War, the policies for affordable housing included other segments of the working class besides the Asia Minor Refugees. Thus, in the area around central Piraeus, in the Municipality of Agios loannis Rentis, the Workers Housing Organization constructed various housing complexes. In addition, after the 1950s, the Ministry of Social Welfare erected social housing clusters in the Municipality of Drapetsona.

After the 1990s, the Workers' Housing Organization inaugurated a new branch in Piraeus so as to facilitate the needs of the local community. According to the interviews with the employees of Piraeus' branch, almost 100.000 citizens participated each year in the Organization's subsidize rental housing program, between 1995-2007. The Organization paid a portion of the rent to market-rate rental units. 
These units were chosen by the beneficiaries within certain requirements. There were also programs that included loans for purchasing an apartment and loans for restorations/renovations in existing private owned apartments. According to the employee's estimation, approximately 50.000 beneficiaries participated each year in these programs too. Unfortunately, as mentioned before, the Organization closed in 2012 as a consequence of the austerity policies, subsequent to the economic crisis of 2008.

As for the neighboring land uses, social housing enclaves in Drapetsona and Agios loannis Rentis are close to manufacturing units, brownfield sites and wholesale facilities. In Nikea and Keratsini, the social housing enclaves are surrounded by residential areas with small local centers for commercial services. Given the expansion of the urban fabric around central Piraeus, the former excluded social housing quarters are now part of the contemporary urban net in proximity to typical blocks of flats constructed through the flats-for land system. However, one major issue that needs addressing, is the high empty property rates despite the widespread property ownership. This empty property rate is associated with an obsolete and devalued social housing stock that was observed mostly in the case of Nikea and in some small scattered enclaves in Drapetsona and Palia Kokkinia (see map 2 and Fig. 1 and 2).
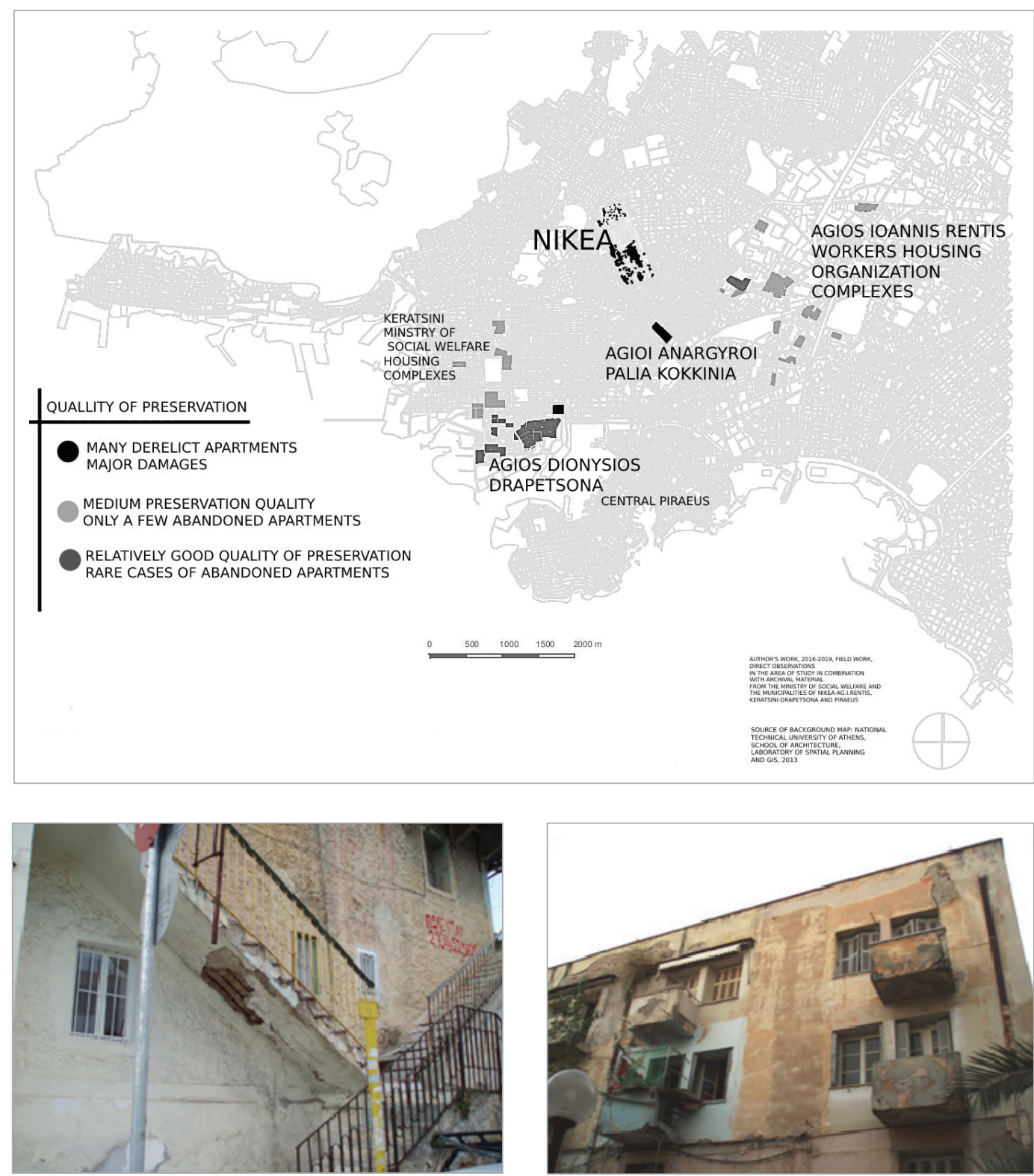

\section{Map 2}

Crucial social housing enclaves in the Greater Piraeus Region, because of the low level of maintenance and the derelict housing reserve, author's field work, 2017-2018

Fig. 1, 2

Devalued social housing stock in Nikea (left) and in Agios Dionysios Drapetsona (right). Author's field work 2016-2018 


\section{Brief socio-spatial analysis of the crucial social housing enclaves in Greater Piraeus Region}

The refugee settlement of Nikea, includes five different types of refugee houses, as presented in the Fig. 3.

Fig. 3

Different architectural types of the refugee houses in Nikea, Author's previous field work (2011)

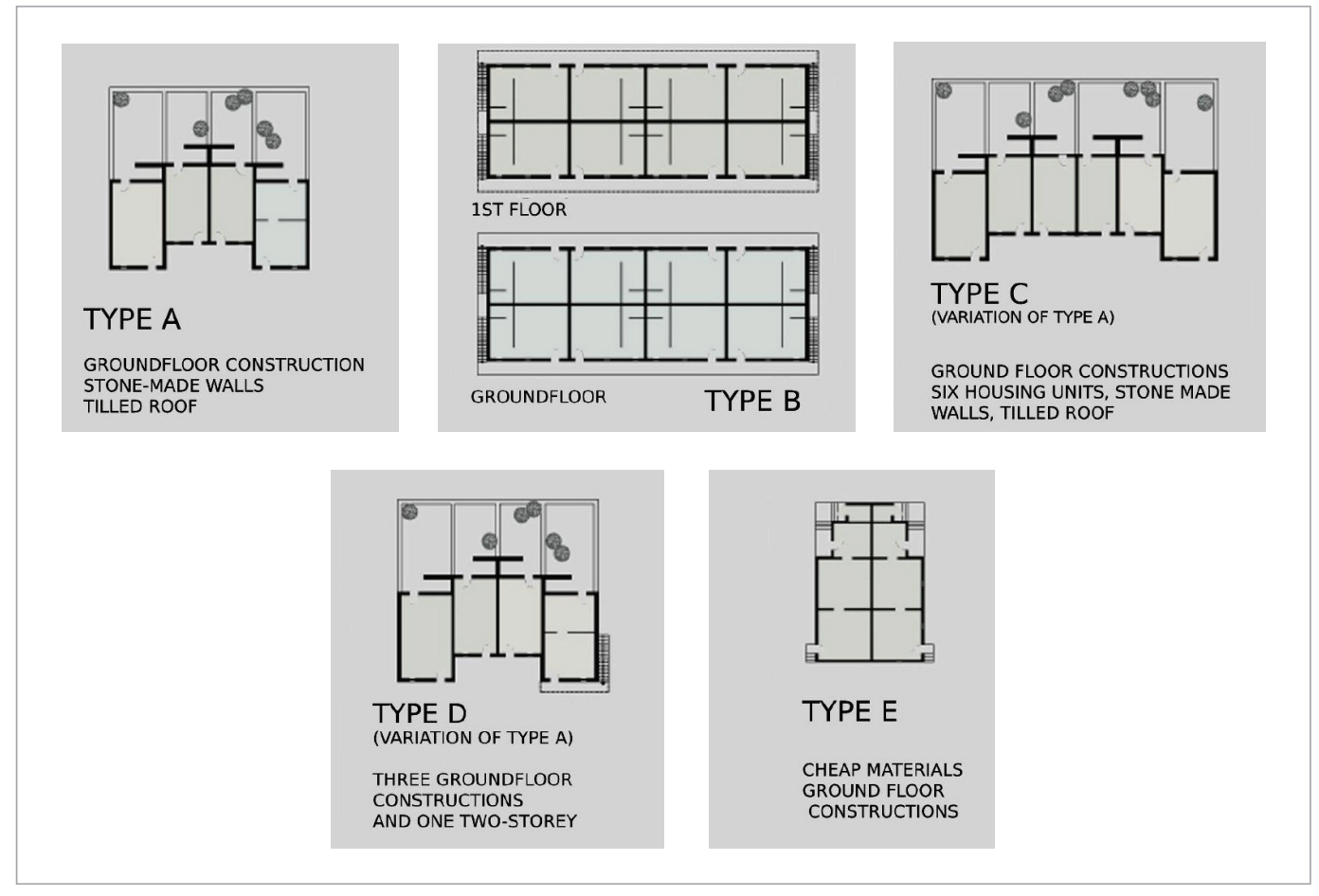

Today, the area preserves almost $40 \%$ of the refugee houses that belong to the five above mentioned architectural types. These refugee apartments host today vulnerable households, mostly economic immigrants and elderly people, descendants of the refugee population. The first immigrants that have been residing in the area since 1995, came from Balkan countries and the former USSR, while recent immigrant inflow is associated with male immigrants from Asian countries after 2005. Low incomes and limited access to social services are some of the common socio-economic characteristics of today's residents.

Nikea's refugee houses offer poor housing facilities; they are about 30 to 60 square meters without central heating services. The rents of the refugee apartments are rather low, about 180-200 euros. According to field work, the price of rent depends on the quality of preservation and the facilities that the apartment offers. Most of the houses have illegal extensions on the pavements and at the common yard that exists in the middle of each city block. The level of maintenance of all these constructions is rather low. In many cases refugee complexes comprise derelict apartments with broken windows and doors together with a few that are still inhabited (see Fig. 4 and 5). After the 1970s and especially after the 1990s, transformations in the urban topography of the area have led to a complex situation where refugee houses co-exist with contemporary blocks of flats. This situation leads to overlapping shadows, inefficient ventilation and limited access to direct sunlight in the case of the old refugee houses.

According to the ETHOS' typology on Homelessness and Housing Exclusion, some of these refugee buildings could be described as not suitable for habitation leaving their tenants as potentially

1 See the official website at https://www.feantsa.org/en/toolkit/2005/04/01/ethos-typology-on-homelessness-andhousing-exclusion 

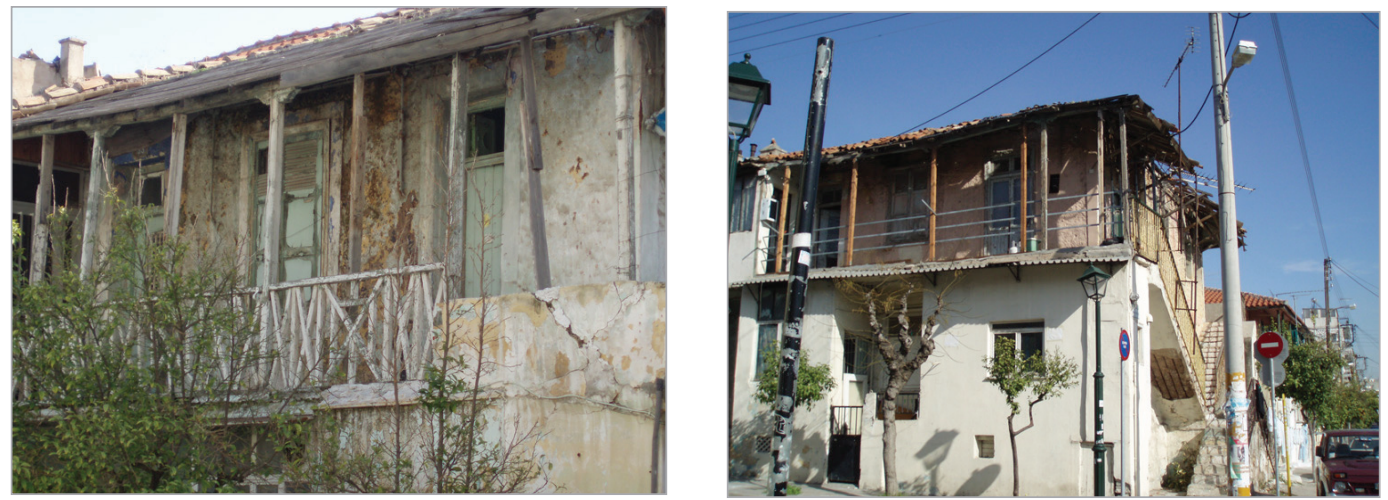

Fig. 4, 5

Contemporary condition of the refugee houses in Nikea, author's field work 2016-2018

homeless. The categories of ETHOS that respond to the case of Nikea are 8.2, 12 and 13. Category 8,2 describes illegal subtenancy that is observed in the case of the economic immigrants that came in Nikea after 2005. Category 12 includes dwellings unfit for habitation while category 13 describes people living in extreme overcrowding conditions. This last category is again linked to the living conditions of the male Asian immigrants that came in Nikea around 2005.

The same situation is observed in the social housing quarter of Agioi Anargiroi, Palia Kokkinia, in Piraeus. This social housing complex was designed after the famous Karl Marx Hof building complex in Vienna, Austria, during the 1930s. It is a concrete construction in a $\Pi$ shaped synthesis that leaves a communal open space in the middle of the block so as to foster social interaction and exchange. According to field work, during the 1980s most of the tenants abandoned their apartments so as to seek for better housing facilities in nearby neighborhoods. Today, only a few apartments are inhabited. The social housing complex has major damages on the structural elements and on the facades. Some apartments are destroyed by fire. Despite the recent regeneration of the communal public space, the area suffers from urban blight (Fig. 6 and 7). Today's residents are mostly immigrants and a few couples of elderly people, characterized by very low incomes. Last but not least, the social housing complex in Agios Dionisis, Drapetsona, is totally devalued because of major damages after the earthquake of 1999 (see Fig. 2). For many years it served as an unofficial shelter for homeless people. The building complex was officially sealed around 2016 because of its perilous condition so as to avoid any kind of accident.

Based on field work, the descendants of the refugee population that still live in these areas are strongly connected to their home and neighborhood. The sense of neighborhood receives a sentimental symbolic value associated with the refugee past. One other important factor that fosters this strong attachment to these neighborhoods is the experience of the Resistance and the WWII. The majority of the citizens in these quarters were highly involved into the organization of the Resistance, participating in numer-
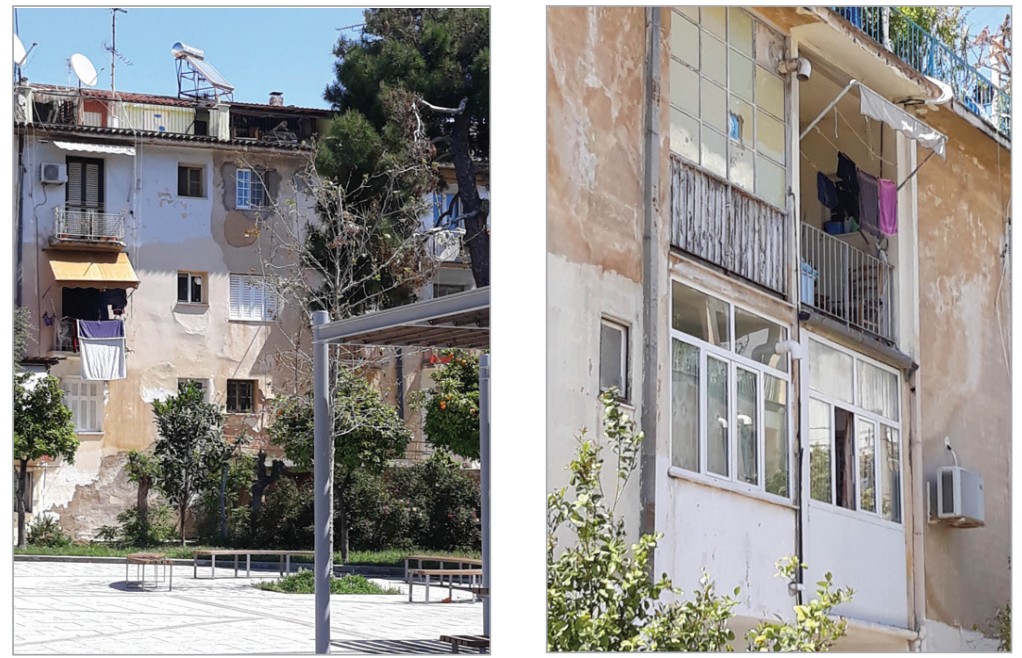

Fig. 8, 9

Contemporary condition of the social housing quarter in Agioi Anargiroi, Palia Kokkinia, Piraeus, author's field work 
ous operations. One such operation took place on the $17^{\text {th }}$ of August in 1944 in Nikea and is called "Mploko Kokkinias"2. The result of this military operation was the execution of 350 people while almost 8.000 people were sent to the concentration camp in Haidari (Attica, Greece). These experiences function as the main core that holds together the old inhabitants despite the difficult housing conditions in the above-mentioned social housing quarters. On the other hand, the immigrants that live in these neighborhoods do not seem strongly attached to the area and they are willing to move in another neighborhood so as to find better housing facilities.

Looking in depth all different quarters of social housing in Piraeus, one could conclude that some of them suffer from urban blight. The cases of Nikea, Agioi Anargiroi-Palia Kokkinia and Agios Dionisios in Drapetsona include obsolete and derelict housing stock, while all the other enclaves offer better housing conditions. These crucial enclaves are associated with the initial type of applied policy, the construction materials and the age of the housing reserve.

The households and individuals that reside in these dwellings are bound to become subject of social exclusion, having limited access to social healthcare system, very low incomes and instable working conditions. In this case, exclusion is connected to poverty, despite the fact that not all forms of exclusion are associated with poverty. Moreover, energy poverty ${ }^{3}$ was also recorded during field work, given the fact that the tenants are not able to cover the expenses needed so as to achieve thermal comfort inside the social housing apartments. In addition, in relevance to the ETHOS typology on Homelessness and Housing Exclusion, contemporary tenants may be described as potentially homeless. Thus, there are certain discrepancies among different social housing complexes inside the Greater Piraeus Region. The exploration of these differences reveals different levels of risk of exclusion in the various social housing quarters of the Greater Piraeus Region.

Given the lack of centralized policies for the refurbishment of the social housing stock, there are dim prospects for the future of these areas. Over the years, the situation is deteriorating even more, leaving these neighborhoods in despair. According to author's prior research in the area (2009-2014), demolitions of old social housing complexes are rare. To be more specific, only one was recorded in ten years (from 2009 to 2019). Thus, the aging social housing reserve is still remaining devalued and obsolete, hosting vulnerable population groups. From this point of view, the issue of regenerating these crucial social housing enclaves should become a high priority in order to strengthen socio-spatial cohesion in peripheral Piraeus.

To combat urban decay and exclusion, further research should be conducted so as to delve into the complex ownership status that these apartments have and which is considered as a major barrier to future development. The numerous heirs in each apartment together with the lack of financing are the two key-obstacles that policy makers have to overcome so as to propose viable solutions for these areas. All in all, these degraded quarters are significant parts of the urban collective memory of the city. Their preservation and restoration is vital, given this long-term degradation that characterizes not only the buildings themselves but also the surrounding public spaces. To leave these neighborhoods in despair would only widen the gap between upscale and blighted urban areas, dispersing urban policies away from the vision of urban sustainability.

\section{Acknowledgements}

The author would like to thank the National Technical University of Athens, School of Architecture and especially Prof. P.Koutrolikou, for hosting and supervising this post-doctorate research from 2016 to 2019. Special acknowledgements are attributed also to the participants of the survey. Participants' contribution was valuable and significant for the final outcome of the research.

2 Reference in Greek: https://el.wikipedia.org/

3 About the term see Csiba,2016. 
Andrusz G. (1984) "Housing and Urban Development in the USSR" Albany: State University of New York Press. https://doi.org/10.1007/978-1-34905218-9

Braga M., Palvarini P.(2013) "Social Housing in the EU”, Directorate General for Internal Policies, Policy Department A: Economic and Scientific Policy ,European Parliament, Brussels

Brat R. (1986) "Public Housing: The Controversy and Contribution" Critical Perspectives on Housing, Philadelphia, Temple University Press, 335-361

Burchardt, T., Le Grand, J., \& Piachaud, C. (1999). Social exclusion in Britain 1991-1995. Social Policy and Administration. 33/3: 227-44. https://doi. org/10.1111/1467-9515.00148

Byrne, D. (1999) Social Exclusion. Buckingham: Open University Press

CECODHAS (2012) "Impact of the crisis and austerity, measures on the housing social sector", European Social Housing Observatory, published at www. housingeurope.eu/publication/research-briefings

Csiba K. (2016) ENERGY POVERTYHANDBOOK

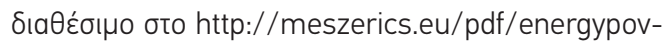
ertyhandbook-online.pdf

Gizeli V. (1984) (1984) «Social transformations and origin of social housing in Greece, Epikairotita, Athens (in Greek )

Estivill, J. (2003). Concepts and strategies for combating social exclusion: an overview. Geneva: International Labour Organisation

Fraser, N. (2003). Redistribución, reconocimiento y exclusión social. In Departamento Administrativo de Bienestar Social (DABS) \& Facultad de Ciencias Políticas y Relaciones Internacionales, Pontificia Universidad Javeriana (eds.) Inclusión social y nuevas ciudadanías. Condiciones para la convivencia y seguridad democráticas. Seminario Internacional. Memorias. Bogotá: DABS, PUJ: 55-69.

Fleury, S. (1998). Política social, exclusión y equidad en América Latina. Nueva Sociedad, $N^{\circ} 156$, Julio-Agosto: 1-25 (pdf version).

Harloe, M. (1995) The people's home? Social rented housing in Europe and America. Oxford: Blackwell.

Jensen-Holt A.(2000) Social Housing: International Comparison of, Planning for the Weakest Social

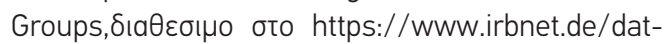
en/iconda/CIB14022.pdf

Juliano, D. (2001). Género y exclusión. In Valencia, A. (ed) Exclusión social y construcción de lo público en Colombia. Bogotá: Centro de Estudios de la Realidad Colombiana (CEREC), Facultad de Ciencias Económicas Universidad del Valle: 27-50.
Koutelakis X., Foskolou A. (1991) Piraeus and neighboring settlements, Bookstore Estia, Athens (in Greek)

Leontidou L. (2017) Slums of Hope, available at Athens Social Atlas, https://www.athenssocialatlas. gr/en/article/slums-of-hope/

Levitas R., Pantazis C., Fahmy E., Gordon D., Lloyd E., Patsios D.,(2007) The multi-dimensional analysis of social exclusion, Department of Sociology and School for Social Policy Townsend Centre for the International Study of Poverty And Bristol Institute

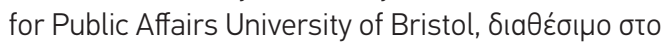
https://dera.ioe.ac.uk/6853/1/multidimensional. pdf

Maarten, H., Manley, D., Bailey, N., Simpson, L., kaı Maclennan, D.,(2012) Neighborhood Effects, Research: New Perspectives, Springer, Ntópvipext/

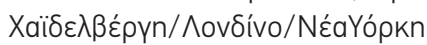

Massey D., Denton N. (1993) "American Apartheid: Segregation and the making of an Underclass" Cambridge, Harvard University Press

Mazel, 0., (1996) L'exclusion. Le social à la dérive, Le Monde/Marabout

Oberleke C.J. (2000) "The evolution of low-income housing policy 1949 to 1999" Housing Policy Debate II (2):489-520. https://doi.org/10.1080/10511482.2 000.9521375

Papadopoulou -Simeonidou P. (1995) City and urban planning in the former USSR 1917-1985, Kyriakidis Publications, Thessaloniki (in Greek)

Paugam, S. (1996) L'Exclusion. L'étatdessaviors, Editions la Decouverte, Paris

Poggio T., Whitehead C. (2017) Social housing in Europe: legacies, new trends and the crisis, Critical Housing Analysis, Volume 4 | Issue 1 | 2017 | 1-10 Available online at www.housing-critical.com, https://doi.org/10.13060/23362839.2017.3.1.319

Sarigiannis G. (2000)Athens 1832-2000, Symmetria publications, Athens (in Greek)

Schnapper D. (2011) Social integration. A contemporary approach, Kritiki Publications, Athens (in Greek)

Spicker P. (1998) "Housing and Social exclusion", Shelter, Scottish Campaign for Homeless people http://www.spicker.uk/open-access/1998\%20 Housing\%20and\%20Exclusion.pdf

Stadelbauer J. (2006) "Moscow: capital of a decimated world power" in Schneider R. Sliwa,(2006) Cities in Transition :Globalization, Political Change and Urban Development (Geo Journal Library). https://doi. org/10.1007/1-4020-3867-4_6

Tousi E., (2014) The urban space as a field of trans-
References 
formation in the light of the refugee issue, $\mathrm{PhD}$ dissertation, National Technical University of Athens, School of Architecture, Sector of Urban and Regional Planning

United Nations (2006) "Guidelines on Social Housing: Principles and Examples", United Nations Publications, Geneva, Switzerland

Waquant L.(1993) "Urban outcasts: Stigma and Division in the black American Ghetto and the French urban periphery", Blackwell Publishers, Oxford, U.K. https://doi.org/10.1111/j.1468-2427.1993.tb00227.x
Waquant L.(2007) "Territorial stigmatization in the age of advanced marginality", Sage publications and Thesis eleven co-op Ltd. https://doi. org/10.1177/0725513607082003

Whitehead C., Scanlon K.(2007) "Social housing in Europe”, LSE, London School of Economics and Political Science, London

Whitehead C., Scanlon K.(2008) "Social housing in Europe II: A review of policies and outcomes", LSE, London School of Economics and Political Science, London

\section{About the Author}

\section{TOUSI EVGENIA}

\section{Dr. Architect-Urban and Regional Planner}

Adjunct Academic Staff, University of West Attica, School of Applied Arts and Culture, Department of Interior Architecture

\section{Main research area}

sustainable urban and regional planning

\section{Address}

E-mail: etousi@uniwa.gr 